\title{
Aligning Belt and Road with Africa's Development
}

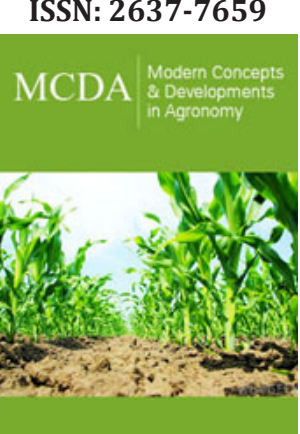

*Corresponding author: Dorathy Onyinye Achu, Postgraduate student, Nanjing, China and the General Secretary for Nigerians in Diaspora Organization East China chapter

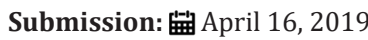

Published: 監April 22, 2019

Volume 4 - Issue 1

How to cite this article: Dorathy 0 A Aligning Belt and Road with Africa's Development. Mod Concep Dev Agrono.4(2). MCDA.000581.2019. DOI: 10.31031/MCDA.2019.04.000581

Copyright@ Dorathy Onyinye Achu, This article is distributed under the terms of the Creative Commons Attribution 4.0 International License, which permits unrestricted use and redistribution provided that the original author and source are credited.

\author{
Dorathy Onyinye Achu* \\ General Secretary for Nigerians in Diaspora Organization East China chapter, China
}

\section{Opinion}

Anywhere Chinese leaders visit, the Belt and Road goes with them-in speeches, if nothing else, butalso frequently in economic pacts and even formal diplomatic documents. That was the situation during this year FOCAC Summit meeting in September. The Belt and Road strategy is centered on infrastructure development, especially regional transportation and connectivity projects. Arguably, the strategy would have two main applications in Africa. The first is the infrastructure development of the continent, which is closely associated with China's need to boost exports, utilize its excess capacity in construction industries, and stimulate China's slowing economic growth. The second is the transfer of labor-intensive industries, especially manufacturing businesses to Africa, so as to complement China's own economic restructuring given its rising manufacturing costs (such as labor costs).

In line with this, President Xi Jinping said on Sept 4, 2018 at the Beijing Summit that "China and Africa will align the Belt and Road Initiative with the development strategies of African countries to bring more opportunities for the growth and prosperity of the continent." However, there is need for good governance to be in place in order to achieve this goal because good governance coupled with the Belt and Road Initiative (BRI) will brings about an upsurge in the economy growth of Africa. The Belt and Road initiative though a recent Chinese initiative is connected to increased economic value and growth across the African continent. African countries with better policies will benefit from this initiative, and a doubling effort will be required to sustain this initiative into continual physical and material developmental benefits. While the Belt and Road Initiative is a welcome development among African countries and opens a new window for friendship between countries, not all countries in the African continent are part of this movement. While some member African countries have indicated interest and joined the initiative, some other countries are still undecided. This year three African countries; Burkina Faso, Gambia, and Sao Tome and Principe were welcomed on board by President Xi Jinping. The Belt and Road initiative has a common goal and is currently an important vehicle for redesigning China-African cooperation and development in this $21^{\text {st }}$ century. The aim is to connect with the United Nations Sustainable goals of exploring new territories and revitalizing weak economies. The wisdom behind the Belt and Road initiative is set to promote regional cooperation, innovation, and technology for all participating members, and will be very supportive to worldwide governance. During the summit held this year on September $3^{\text {rd }}$ and $4^{\text {th }}$. President Xi Jinping introduced eight new initiatives. This initiative includes provision of infrastructure connectivity, promotion of trade between continents, green development, capacity building, healthcare, people-to-people exchanges, peace and security with great focus on strengthening and building of local capacity. This also includes workshop activities designed to promote modern vocational training and offer technical skills and know how. That goes to say skills acquisitions, transfer of operational tasks from the Chinese counterparts. is part of the developmental agreement. China-Africa cooperation has improved significantly in various fields in recent years, and the Belt and Road Initiative has expanded bilateral cooperation in a broader sense. For example, Construction has helped in propelling trade between Africa and China recently and Export \& Import volume is seen to have increased via construction projects taking place between some African countries and 
China economies as the Ministry of Commerce in China reported an $18.7 \%$ year -on-year increase, and over $\$ 116$ billion just within the first seven month in 2018.

The Belt and road initiative are also a good way for African countries to engage China in her Project development as Funds could be generated through loans and direct investment. Banks such as the Asian Infrastructure Investment Bank founded in 2015, New Development Bank, that was set up by China and some emerging countries was established to render assistance to striving economies. These banks assist in paying for infrastructural developmental projects and invest in African countries through loans and aids. Also, the newly created agency- China International Development Cooperation Agency (CIDCA) structured to coordinate China's foreign aid program is in line with the Belt Road Initiative. The BRI together with mutual cooperation between Africa and China looks to transforming Africa from her anti-industrialized state, retarded growth which was crippled by western reforms in the 1980's to a comprehensively economic and socially transformed continent through accelerating technology transfer and employment creation. 